\title{
Incidence of nodal rooting and plantlet survival in spreading red clovers
}

\author{
M.G. HYSLOP, P.D. KEMP, D.J. BARKER' and J. HODGSON \\ Department of Plant Science, Massey University, Palmerston North \\ 'AgResearch Grasslands, Private Bag 11008, Palmerston North
}

\section{Abstract}

Red clover (Trifolium pratense L.) can provide high quality summer feed but has declined in popularity owing to its poor persistency in temperate grazing systems. From 1991 to 1996 the incidence of nodal rooting of prostrate selections of red clover was quantified and the survival of the resulting plantlets was tracked over time, under grazing conditions. Three field experiments were conducted using Astred, Grasslands Pawera, F2419 and Grasslands Turoa selections of red clover. The main experiment comprised 3 harvests (plants and plantlets dug up) of 3 red clover selections, in a randomised complete block design with no grazing. The subsidiary plantlet survival experiment followed the life and death of 160 plantlets from the three selections under rotational grazing to $5 \mathrm{~cm}$, over a period of 48 weeks. The numbers of plantlets produced per parent plant of each selection were 37, 16 and 5 for Astred, F2419 and Turoa, respectively $(\mathrm{P}<0.001)$. Astred produced significantly larger plantlets $(\mathrm{P}<0.001$, mean $=130.6 \mathrm{~g} /$ DM/plantlet) over 7 months than F2419 and Turoa (means $=31.5$ and $10 \mathrm{~g} / \mathrm{DM} /$ plantlet, respectively). At week 48 plantlet survival ranged from $84 \%$ (Astred) to $27 \%$ (Turoa) $\quad(\mathrm{P}<0.001)$. The experiment at Ballantrae consisted of oversowing $20 \mathrm{~kg} / \mathrm{ha}$ of 2 clover selections (Pawera, creeping selection) into sprayed pasture in 1991. Plant density, pasture composition and herbage accumulation were measured until 1995, with all treatments continuously stocked at 16 ewes/ha. Pawera contributed only $1.1 \%$ to herbage accumulation during the second year when oversown on hill country and disappeared from the sward soon-after. On-average. the creeping selection made up $3.2 \%$ of the total sward herbage accumulation from years 2 to 5 . It was concluded that the spreading red clovers represented by Astred and F2419 selections have the potential to be more persistent than crown red clovers under grazing.

K eywords: nodal rooting, plantlet, spreading red clover, Trifolium pratense
Introduction

Red clover (Trifolium pratense L.) is one of the least persistent clovers in temperate pastures, particularly where grazing pressure is high (Cosgrove et al.1985), yet it is a valuable source of high quality summer feed in some farming systems. All red clover cultivars used in New Zealand grow from crowns and predominantly reproduce from seed. The crowns are susceptible to treading damage and fungal infection, particularly in winter, resulting in poor persistence (Hay et al. 1989). Pure stands of red clover usually only persist 3-4 years.

Red clover selections exist that have prostrate stems that produce clonal plants at nodes which may improve persistency in grazed pastures. This red clover type is termed spreading in this paper. A cultivar of a vegetatively spreading red clover, Astred, was more persistent than cultivars Grasslands Turoa, Grasslands Hamua and Redwest when grazed with sheep over a 3 year period in Tasmania (Smith et al. 1993). Nevertheless, the perennation and productivity of spreading red clovers requires further evaluation to determine their potential in New Zealand farming systems, and to develop appropriate management s $t$ a $t$ e $g$ i e s.

The objective of this research was to quantify the incidence of nodal rooting of prostrate selections of red clover (creeping and spreading) and to track the survival of the resulting plantlets over time, under grazing conditions in New Zealand.

\section{M aterials and methods}

Three field experiments were conducted using selections of red clover, cv. Astred, cv. Grasslands Turoa and F241-9-(breeding-materialfrom AgResearch_Grasslands).

All three red clover selections have a prostrate growth habit and are known to produce plantlets. Experiments on morphological development and plantlet survival were undertaken on the Pasture and Crop Research Unit, Massey University, Palmerston North, New Zealand (latitude $40^{\circ} 23^{\prime} \mathrm{S}$ ) from May 1995 to May 1996. The soil type was a Tokomaru silt loam, with $\mathrm{pH} 5.7$ and Olsen $P 17 \mu \mathrm{g} / \mathrm{g}$ soil. The area has an annual rainfall of $995 \mathrm{~mm}$ (IO-year average) and mean annual soil 
temperature at $100 \mathrm{~mm}$ of $12.8^{\circ} \mathrm{C}$ (IO-year average). The long-term persistency trial was conducted at Ballantrae Hill Country Research Station, $20 \mathrm{~km}$ north west of Palmcrston North on a 5" west-facing slope, from May 1991 to May 1996. The soil type of this site was a Ngamoka silt loam soil type, pH 5.5 and an Olsen P of $18 \mu \mathrm{g} / \mathrm{g}$ soil.

\section{Morphological experiment}

The experiment comprised a 3 (selections) $\times 3$ (harvests) in factorial combination using randomised complete block design with 10 replicates. Blocks were $7 \mathrm{~m} \times 5 \mathrm{~m}$. Seedlings were randomly planted out within blocks in September 1994 and grazed 4 times to $10 \mathrm{~cm}$ over the spring-summer period by mature ewes. No grazing took place after February 1995. Parent plants and their surrounding plantlets were dug up when the parent plants were 9,13 and 16 months of age from sowing (autumn, late winter and summer respectively) and washed by hand. Weeds and white clover between plants were controlled with Buster@' (glufosinate-ammonium) applied using a weed wiper at 3 parts water/l part herbicide.

Plantlets per parent plant, plantlet weight, plantlet root weight, rooted nodes per parent plant, nodal root weight, parent plant weight (leaf, stem, tap-root weight) were measured. All samples were oven-dried at $80^{\circ} \mathrm{C}$ for dry mass.

\section{Tagged plantlets}

This experiment consisted of 3 selections of red clover compared using a completely randomised design. Seedlings were planted in September 1994. Parent plants were grazed by mature ewes 4 times to $10 \mathrm{~cm}$ over the spring-summer period of 1994 and then down'to $5 \mathrm{~cm}$ in May, October, December, February and May 19951996 respectively.

Fourteen parent plants from each selection (Astred, F2419, Turoa) were randomly chosen and their plantlets tagged with sheep ear tags on wire pegs. Sixty-nine Astred, 48 F2419 and 43 Turoa plantlets were tagged, and plantlet survival was recorded in May, September, December, February and May. Total experimental area was $14 \mathrm{~m} \times 10 \mathrm{~m}$.

\section{Long-term persistency trial}

There were 3 treatments (creeping selection, Grasslands Pawera, untreated resident pasture) in a randomised complete block design with 4 replicates. Plots were $2 \mathrm{~m}$ x $2 \mathrm{~m}$. Red clover treatments were sprayed with 2 । Roundup@ (36\% glyphosate) in 300 I water per ha on 2 May 1991, and were either oversown with $20 \mathrm{~kg} / \mathrm{ha}$ of Pawera or a spreading red clover selection including F2419 (hereafter termed the creeping selection). Germination (standard test) was approximately 90\%.
The experimental area was continuously stocked with 16 ewes/ha.

Red clover seedling density was measured at 37,72 and 98 days after sowing. Herbage accumulation was measured with a cut-and-trim technique using $0.5 \mathrm{~m}^{2}$ exclosure cages between 27 August 1991 and 22 February 1996. Pasture in the cage was cut to approximately $2 \mathrm{~cm}$ in height, 6 times per year, at an average mass of $2800 \mathrm{~kg} \mathrm{DM} / \mathrm{ha}$ above cutting height. Cages were moved after each cut. Botanical composition was determined from subsamples dissected into red clover, white clover and other species.

\section{Results}

\section{Morphological experiment}

Total parent-plant weight at harvest $1(15 / 5 / 95)$ was not significantly different among the three selections, with means of 199.4, 148.5, $233.9 \mathrm{~g}$ DM/parent plant $(\mathrm{SEM}= \pm 38.5)$ for Astred, F2419 and Turoa respectively. There were no significant differences between selections in the ratio of stem (stolon) to total parent plant weight (Astred 56:44, F2419 65:35, and Turoa 63:37).

There was a significant difference $(\mathrm{P}<0.001)$ in the number of plantlets produced by each selection (Table I), the overall means being 37, 16 and 5 for Astred, F2419 and Turoa, respectively.

Rooted nodes per parent plant included rooted plantlets and roots from nodes with no shoots above. Astred produced significantly more $(\mathrm{P}<0.01)$ rooted nodes than the other two selections. Significantly more rooted nodes $(\mathrm{P}<0.01)$ were present at the $15 / 5 / 95$ harvest, $($ mean $=61)$ than at any other time.

Table 1 The number of plantlets and rooted nodes per parent plant at each harvest from 15 May 1995 to 11 Decembe 1995

\begin{tabular}{lcccccc}
\hline & \multicolumn{2}{c}{ Plantlets per } & \multicolumn{3}{c}{ Rooted nodes per } \\
parent plant & & \multicolumn{2}{c}{ parent plant } \\
Harvests: & May & Sept & Dec & May & Sept & Dec \\
\hline Astred & 43 & 25 & 42 & 107 & 36 & 42 \\
F2419 & 16 & 14 & 16 & $\mathbf{2 5}$ & $\mathbf{4 0}$ & $\mathbf{3 7}$ \\
Turoa & $\mathbf{5}$ & $\mathbf{5}$ & $\mathbf{6}$ & $\mathbf{5 0}$ & $\mathbf{5 3}$ & $\mathbf{2 2}$ \\
SEM & & $\mathbf{\pm 5 . 1}$ & & & fll.5 & \\
\hline
\end{tabular}

Astred produced significantly larger plantlets over the assessment period of 7 months when compared to the other two selections $(\mathrm{P}<0.001$, means of $130.6,31.5$ and $10 \mathrm{~g} / \mathrm{DM} / \mathrm{plantlet}$ for Astred, F2419, Turoa, respectively) (Table 2). Astred plantlets were significantly larger $(\mathrm{P}<0.001$ than F2419 and Turoa.

There were no differences in the shoot:root ratio across the three selections, but there was a significant 
difference $(\mathrm{P}<0.001)$ over the harvest times, with means of $12.2: 1,8.7: 1,5.2: 1$ for summer, autumn and winter respectively (Table 2 ).

\section{T a g g e d plantlet}

Table 3 shows the percentage of the originally tagged plantlets of the three red clover selections surviving at each assessment, under rotational grazing. At week 15 there were no significant differences across selections, but by week 27 and 37 significantly more Astred plantlets remained than for the other two selections, and by week 48 the percentage of remaining plantlets was greatest for Astred and least for Turoa $(\mathrm{P}<0.05$, Table 3).

\section{Long-term persistency trial}

There was no significant difference in seedling density measured over 3 dates, averaging 343 and 564 seedlings $\mathrm{m}^{2}$ for Pawera and creeping selection, respectively (mean SEM 138 seedlings $/ \mathrm{m}^{2}$ ).

The contribution of red clover to total herbage accumulation was not significantly different between red clover treatments during the first year (8 and 11\% for Pawera and creeping, respectively, Figure 1). However, Pawera contributed only $1.1 \%$ to yield during the second year and disappeared from the sward soon after. On average, the creeping selection made up $3.2 \%$ of the yield from years 2 to 5 . There was seasonal variation in its contribution which was greatest in late summer $(7.5 \%)$ and least in winter $(2.1 \%)$.
Table 2 Total plantlct mass (g), and plantlet shootroot ratio,

\begin{tabular}{lcccccc}
\hline \multicolumn{3}{c}{ Total } & plantlet mass (g) & \multicolumn{2}{c}{$\begin{array}{c}\text { Plantlet } \\
\text { shoot:root ratio }\end{array}$} \\
Harvests: & M a y & Sept & Dec & May & Sept & Dec \\
\hline Astred & 15.9 & 28.0 & 348.0 & $5.8: 1$ & $4.6: 1$ & $12.4: 1$ \\
F2419 & 6.8 & 10.3 & 77.44 & $9.5: 1$ & $6.9: 1$ & $14.0: 1$ \\
Turoa & 1.6 & 2.3 & 26.2 & $10.8: 1$ & $4.0: 1$ & $10.2: 1$ \\
SEM & & \pm 29.4 & & & \pm 1.8 & \\
\hline
\end{tabular}

Table 3 The percentage of tagged plantlets remaining after 48 weeks under rotational grazing by mature ewes.

\begin{tabular}{|c|c|c|c|c|c|}
\hline Recordings: & We ek & $\begin{array}{c}\text { Week } \\
15\end{array}$ & $\begin{array}{c}\text { Week } \\
27\end{array}$ & $\begin{array}{c}\text { Week } \\
37\end{array}$ & $\begin{array}{c}\text { Week } \\
48\end{array}$ \\
\hline $\begin{array}{l}\text { Astred } \\
\text { F2419 }\end{array}$ & $\begin{array}{l}100 \\
100\end{array}$ & $\begin{array}{c}100 \\
86.9\end{array}$ & $\begin{array}{l}90.4 \\
64.6\end{array}$ & $\begin{array}{l}85.0 \\
52.4\end{array}$ & $\begin{array}{l}83.8 \\
52.4\end{array}$ \\
\hline $\begin{array}{l}\text { Turoa } \\
\text { SEM }\end{array}$ & 100 & 87.8 & $\begin{array}{l}62.6 \\
\pm 7.9\end{array}$ & 40.1 & 26.9 \\
\hline
\end{tabular}

White clover yield was not significantly different among the 3 treatments ( $>0.05$ ), and averaged 9.4, 9.8 , and $9.5 \%$ of yield over 4 years for the control, Pawcra and creeping selection, respectively.

Annual total herbage accumulation of the control treatment (resident pasture) was significantly greater than that of the red clover treatments in year $1(\mathrm{P}>0.001)$ (16 000 vs $12500 \mathrm{~kg} \mathrm{DM} / \mathrm{ha} / \mathrm{yr}$ ). Annual total herbage accumulation of the Pawera treatment was significantly greater than for the other two treatments in year 2 $(\mathrm{P}>0.05)(15000$ vs $12900 \mathrm{~kg} \mathrm{DM} / \mathrm{ha} / \mathrm{yr})$. Annual yield

Figure 1 Contribution to yield (\%) for Pawera, a crown-type cultivar, and a spreading red clover, "creeping selection" over 5 years of continuous sheep grazing in well-fertilised hill country pasture.

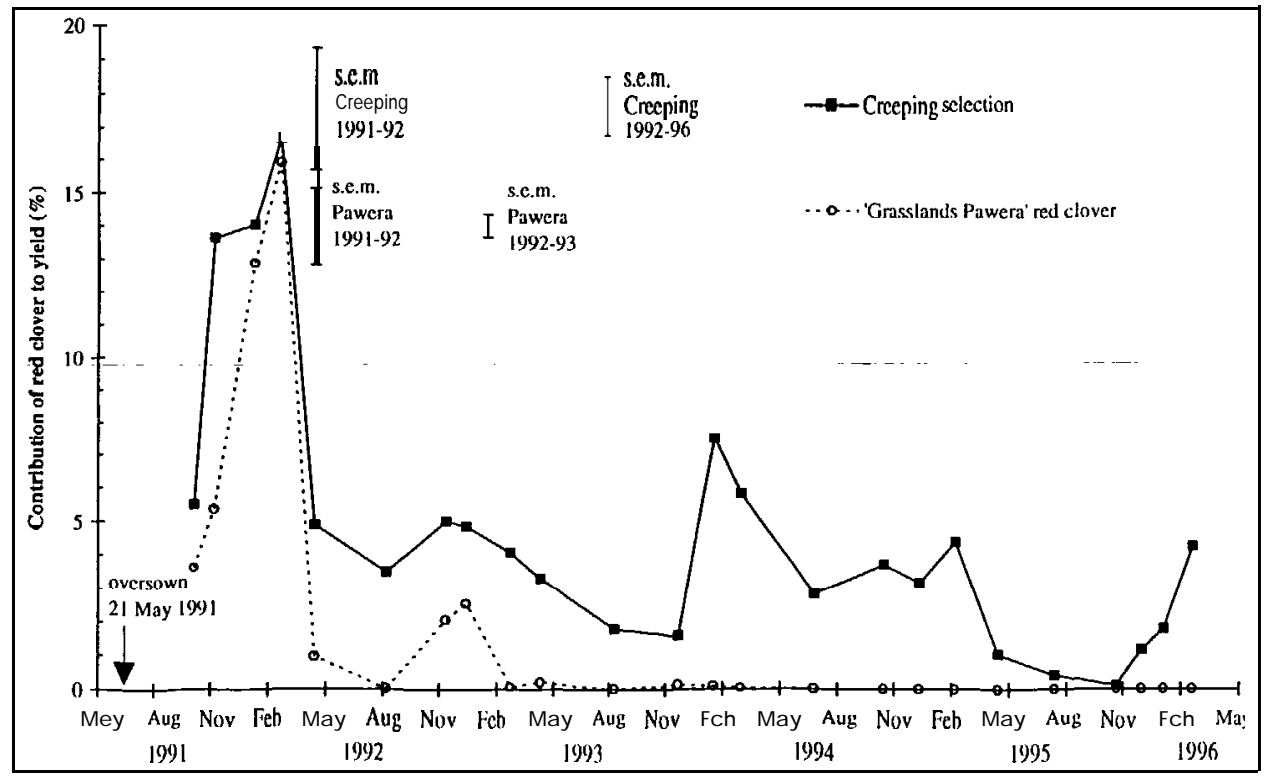


did not vary across treatments in years 3 and $4(P>0.05)$ (mean $=15200 \mathrm{~kg} \mathrm{DM} / \mathrm{ha} / \mathrm{yr}$ )

\section{Discussion}

All the spreading red clover selections, Astred, F2419, Turoa, and the creeping selection, developed independent plantlets on stem nodes. Astred was the most prolific producer of plantlets and these were larger and more likely to survive than those from F2419 and Turoa. Astred also spread more than the other selections with plantlets up to $900 \mathrm{~mm}$ from the parent plant compared with $150 \mathrm{~mm}$ for Turoa plantlets. It was observed $\boldsymbol{i n}$ the field that vegetatively produced Astred plantlets themselves developed plantlets on their stems after one year.

The similar mass of the parent plants of Astred, F2419 and Turoa and the similar allocation of mass to stem tissue suggested that the growth potential of Astred was not disadvantaged by its abundant plantlet production. A key difference between the selections appeared to be the capacity to produce plantlets at rooted nodes rather than the development of rooted nodes (Table 1). A comparison of the morphological (no grazing) and tagged plantlet (grazing) experiments suggests that grazing affects plantlet survival, and the number of rooted nodes that develop plantlets. Field observations have suggested that Astred parent plants are less persistent than those of some other selections of red clover. A demographic study of the development and lifespan of plantlets and parent plants is required.

Turoa has a long history of use in New Zealand and has poor persistency despite being able to develop plantlets (Hay et al. 1989). Turoa plantlets were shown to be small in size and number, and to be short lived and therefore ineffective. Similarly, Smith et al. (1993) showed that under set stocking with sheep in Tasmania, Turoa declined to $5 \%$ ground cover after 15 years, whereas Astred retained $55 \%$ ground cover.

The creeping selection of red clover used at Ballantrae was persistent under hill country grazing relative to Pawera. Although the contribution to herbage mass was highly seasonal, the creeping selection, based on F2419, appeared to have established a stable population after year two. The persistence of the creeping red clover at Ballantrae was not at the expense of white clover in the sward. White clover content in thecreeping treatment was similar to that of resident and Pawera treatments, and total legume content was greatest in the creeping treatment.

In conclusion, the Astred and the F2419 selections, owing to their capacity to maintain a plant population by vegetative reproduction, have the potential to bc more persistent under grazing than red clovers restricted to growth from a crown. Nevertheless, further research on the performance under grazing of these spreading red clovers in pure and mixed swards is required.

\section{ACKNOWLEDGEMENTS}

The authors are grateful to T. Lynch. M. Osborne and N. Dymock for their technical assistance in the field and to R. Richardson, Y. Gray and the staff at the AgResearch Grasslands herbage laboratory for help with plant dissection. The authors also wish to thank W. Rumball for the provision of seed, D. Real for plant material and the D.J. McGowan Scholarship for financial assistance.

\section{REFERENCES}

Cosgrove, G.P.; Brougham, R.W. 1965. Grazing management influences on seasonality and performance of ryegrass and red clover in a mixture. Proceedings of the New Zealand Grassland Association 46: 71-76.

Hay, R.J.M.; Ryan, D.L. 1989. A review of 10 years research with red clovers undergrazing in Southland. Proceedings of the New Zealand Grassland Association 50: 181-187.

Smith, R.S.; Bishop, D.J. 1993. Astred - a stoloniferous red clover. Proceedings of the XVII International Grassland Congress 1993: 421-423. 